\title{
Replication Initiation Gene
}

National Cancer Institute

\section{Source}

National Cancer Institute. Replication Initiation Gene. NCI Thesaurus. Code C20370.

Replication Initiation Genes encode proteins directly involved in initiation of DNA replication. $(\mathrm{NCl})$ 